\title{
Performance Appraisal as Manager's Effort to Increase Employee Productivity at Textil Company PT. Indonesian Tootal Thread in Pasuruan
}

\author{
Nunuk Indarti ${ }^{1}$, Nurus Sobakh ${ }^{2}$, Dies Nurhayati ${ }^{3}$, Ninik Suryatiningsih ${ }^{4}$, Sugeng \\ Pradikto $^{5}$ \\ 1, 2,3, 5 Study Program of Economics Education, Fakulty of Pedagogy and Psychology, \\ Universitas PGRI Wiranegara Pasuruan, Jawa Timur, Indonesia. \\ ${ }^{4}$ Study Program of English Language Education, Fakulty of Pedagogy and \\ Psychology, Universitas PGRI Wiranegara Pasuruan, Jawa Timur, Indonesia.
}

*Corresponding Author: nunukindarti53@gmail.com

\begin{abstract}
The implementation of achieving goals is not an easy thing for the business world; increasingly fierce competition is a difficult barrier. These issues require management to plan, organize, direct, and supervise the resources that are owned appropriately and with useful results. One of the efforts to increase employee productivity in the company is performance appraisal. With this performance appraisal, employee performance can be improved according to their field of work. The efforts that have been made by the company in assessing employee performance are by assessing responsibility, loyalty, and obedience in the hope that employees will work by the directions given for the achievement of company goals. In research entitled "Performance Appraisal as an Effort Manager in order to increase the productivity of employees in order to increase the productivity of employees, "aims to determine the effect of performance appraisal as an effort of managers to work productivity of employees by taking research studies on the textile company" PT. Tootal Thread Indonesia in Pasuruan. By the purpose of this study, the analysis method used to test the hypothesis is a statistical method, where the stages of research analysis use SPSS as a tool and data obtained from employees of the Pasuruan textile company as many as 25 respondents. Carried out based on statistical methods, it can be obtained that in essence, all the performance appraisal factors given to employees together have a significant influence on employee productivity because performance appraisals in the form of responsibility, loyalty, and obedience can lead to goodwill towards employees. Employees carrying out the company's tasks and responsibilities have the most significant influence on work productivity because, with responsibility, employees can complete their work correctly.
\end{abstract}

Keywords: Performance appraisal, Productivity, Textil Company 


\section{Introduction}

Every company that carries out its activities intending to produce goods in order to maintain company operations. To meet the company's goals, the company leadership tries to evaluate employee performance as an effort of managers to increase productivity so that employees can produce quality products to achieve company goals. With performance appraisal, employees feel cared for so that they grow enthusiastically to work harder so that all company activities can be carried out according to the plan that has been set before [1]; [2].

To carry out the planned plan to be adequately implemented, the company will improve the quality and better standards, so that the textile company PT. Tootal Thread Indonesia can compete with other companies. In connection with improving quality and better standards, the company takes by assessing performance and maintaining the products produced so that they have superior quality as expected by the company. In connection with improving quality and better standards, the company takes by assessing performance and maintaining the products produced so that they have superior quality as expected by the company.

In today's economic conditions, companies are expected to have the optimal performance to affect production output. The essential factor in getting optimal performance lies in human resources because of human resources because human resources are the company's main assets. If human resources are not right, it will have an impact on the survival and development of a company [3]. Performance appraisal is a process that measures employee performance [4]. Performance appraisals can provide helpful information in making and implementing decisions on promotions, raises, dismissals, and transfers.

From the description above, it can be taken into consideration and the duty of a manager in conducting performance appraisals, by the intent of management itself to conduct a study. Based on the above problems, it is necessary to have a problem formulation that can later be obtained the right way of the results that are as expected and can provide benefits to interested parties. The focus of this research is:

1. To what extent is the effect of performance appraisal on employee work productivity at PT. Indonesian Tootal Thread in Pasuruan

2. Which performance appraisal factors have the most significant influence on employee work productivity at PT. Indonesian Tootal Thread in Pasuruan

\section{Literature Review}

\subsection{Performance Assessment}

According to [5] 1) Performance appraisal is a systematic (regular) awareness (description) of the relevance of tasks and their implementation by a worker. 2). Performance appraisal is an effort to identify, measure (assess), and manage (management) the work carried out by workers (HR) within an organization/company, 3). Performance appraisal is an activity to identify the implementation of work by assessing its aspects, which is focused on work that affects the organization /company's success / company, 4). Performance appraisal is a measurement activity to make decisions about success or failure in carrying out work by a worker; for that, we need to formulate work standards as a comparison.

\subsection{Productivity}

Ahyari, Agus (2002) [6] defines productivity as a comparison of the actual results of activities with what they should be. Moreover, expressed in numbers, the amount of productivity ranges from 0 to $100 \%$. According to [7]; [8], productivity is a term that defines the relationship between products (the number of products and services produced) and inputs (the quantity of labor, money, property, electricity, etc.) used to produce these results. According [8], productivity can be considered as an output or input, then productivity (according to what is defined by the department of labor) is a mental attitude that always has the view that the quality of life today must be better than yesterday.

\section{Method}




\subsection{Type of Research}

To find out scientific truth, it is necessary to have an appropriate research method; in this case, it is a type of research that is a suitable research hypothesis, bearing in mind: "Research is an investigation of a field of science that is carried out to obtain facts or principles patiently and carefully. Careful, as well as systematic. While testing, research is a descriptive study highlighting the relationship between research variables and tests the previously formulated hypotheses. Therefore, this type of research is very appropriate to test the relationship between performance research on work productivity.

3.2 Variables and Measurements

\subsubsection{Variable}

To know and get to know the concepts of the variables under study, the variables are:

a. Independent variable, the variables studied the performance appraisal. The variables are

1. Responsibility

Namely, a worker can complete the tasks and work assigned to him as well as possible and on time and dare to take risks or decisions he makes.

2. Loyalty

Determination and the desire to follow, execute and practice anything obeyed with complete knowledge and obligation. This commitment and skill must be proven by the workers' conduct and behavior in their everyday tasks and fulfill their assigned roles and occupations.

3. Job performance

Namely, the effects of a worker's performance of the tasks and jobs assigned to him. Overall, a worker's job success is influenced by its expertise, skills, and severity.

4. Obedience

Namely, a worker's ability to comply with all provisions, laws and regulations and relevant official regulations, comply with official orders provided by a professional supervisor, and not infringe any prohibitions defined by the organization, either or in writing.

5. Honesty

Namely, workers' honesty in conducting duties and roles and the capacity not to misuse their authority.

6. Cooperation

A workforce can work together with others to complete a predetermined task and achieve maximum usability and efficiency.

7. Initiative

Namely, the willingness of staff to take actions, take measures or take action necessary to execute the main task without waiting for directives and line manager instructions.

8. Leadership

Namely, a worker's willingness to encourage others to be maximally mobilized to carry out their essential tasks. Assessment of the employee leadership aspect is primarily designed for employees with roles and businesses, both top management, mid-management, and law management.

There are three variables taken by the author in this study, namely:

1) Responsible 
Namely, a worker can complete the tasks and work assigned to him and possible and on time and dare to take risks or decisions he has taken.

Items that are covered by responsibility are:

- Ability to exercise authority and responsibility

- Minimizes the risk of mistakes

- Discipline in carrying out duties

2) Loyalty

Namely, determination and the ability to obey, implement, and practice something obeyed with full awareness and responsibility. Loyalty items include:

- Ability to comply with regulations

- Ability to carry out work

- The suitability of time in carrying out work

3) Obedience

Namely, the ability of a worker to comply with all applicable provisions, laws, and regulations. Items included in the compliance are:

- Ability to do tasks according to the provisions

- Ability to comply with regulations

- Timeliness in carrying out work

b. The dependent variable, the variables studied about work productivity, results from continuous interaction between individual workers and their environment.

- Standard time set

- Expected product quality

- Low level of damage

\subsubsection{Measurement}

For the size of the collected questionnaire data, the authors use the criteria with a score as follows:

If answer

A: is given a score of 5

B: given a score of 4

C: given a score of 3

$\mathrm{D}$ : given a score of 2

E: given a score of 1

\section{a. Reliability Test}

After the measuring device is declared valid, the level of reliability is sought, in the sense of whether the tool is indeed reliable. What is meant by reliability is an index that shows how the measurement results remain consistent if two or more measurements are made of the same symptoms with the same measuring instrument.

b. Validity test

Validity is an index that shows the extent to which a measuring tool needs to be measured. Before testing the correlation between the level of responsibility, loyalty, and obedience with work productivity, the questionnaire validity level is first tested as a tool to measure work productivity. A valid instrument has high validity. To test the level of reliability and validity tested with the productmoment correlation formula:

The relationship between items for each variable is reliable as well as each item to the variable is valid (Appendix I) 


\subsection{Population and Sampling}

In research, it is necessary to establish appropriate research rules; this can be done by researching as a whole or taking samples from the total population. Determining respondents by population method can be done if the number of respondents understudy is small, while unit determination using samples can be done if the number of respondents taken is large enough. In accordance with this research, the technique used in determining the sample is random sampling. Random sampling is a sample taken so that each unit of analysis and elementary units of the population have the same chance of being selected as a sample [9].

The number of employees in the production section is 250 people, the sample taken is $10 \%$ of the total production section so that the sample studied is 25 people with the random sampling method (simple random sample), i.e., samples obtained based on each emergent sampling have the same opportunity/opportunity. The method of selecting samples is done by recording all production employees based on serial numbers, and from these numbers, 25 lottery numbers are selected.

\subsection{Research Instruments}

In researching success in data collection, several instruments are used as follows:

a. Observation

Namely the collection of data by systematically observing and recording the symptoms or phenomena being studied

b. Questionnaire

Namely by holding questions and answers directly to the company, both leaders and employees. Questionnaires were conducted to obtain responses about employee performance regarding responsibility, loyalty, and productivity.

c. Documentary

Namely, by obtaining data and documents archived in the company being researched, the company's state can be known in previous years.

\subsection{Method of Analysis}

a. Qualitative Data Analysis

Namely, a data analyst who uses numbers but uses detailed information. In this case, the writer uses a theoretical approach with existing theories and by means of logical thinking, which is expected to support problem-solving later.

b. Quantitative Data Analysis

Namely, data analysis that uses numbers to prove the interrelated variables. In this case, the writer uses correlation analysis and regression line method with the following formula:

c. Multiple correlations

To test the truth of the first hypothesis, the following formula is used:

$$
\begin{gathered}
{\sqrt{r^{2}}}_{\mathrm{y} 1+\mathrm{r}^{2} \mathrm{y}^{2}-2 \mathrm{r}_{\mathrm{y} 1} \mathrm{r}_{2} \mathrm{r}_{12}} \\
\mathrm{R}_{\mathrm{y} \cdot 12}=-\mathrm{-r}_{12}
\end{gathered}
$$

The test tool used is multiple correlations with a certain level of significance $(\alpha=5 \%)$; the criteria are defined as follows:

Accept Ho if F count $<\mathrm{F}$ table, or reject Ho if $\mathrm{F}$ count $>\mathrm{F}$ table

d. Multiple Regression

To see the relationship between two variables, namely the independent variable and the dependent variable, as well as to check which one is the most dominant among the independent variables through the following formula:

$\mathrm{Y}=\mathrm{a}+\mathrm{b} 1 \mathrm{x} 1+\mathrm{b} 2 \times 2+\mathrm{b} 3 \times 3+b n \times n$

Koefisien regresi dapat dicari dengan rumus sebagai berikut: 


$$
\begin{gathered}
\mathrm{B} 1=\frac{\left(\sum \mathrm{x} 1 \mathrm{y}\right)\left(\sum \mathrm{x} 2^{2} \mathrm{y}\right)-\left(\sum \mathrm{x} 2 \mathrm{y}\right)\left(\sum \mathrm{x} 12\right)}{\left(\sum \mathrm{x} 1^{2}\right)\left(\sum \mathrm{x} 2^{2} \mathrm{y}\right)-\left(\sum \mathrm{x} 1 \mathrm{x} 2\right)\left(\sum \mathrm{x} 12\right)} \\
\mathrm{B} 2=\frac{\left(\sum \mathrm{x} 1^{2}\right)\left(\sum \mathrm{x} 2 \mathrm{y}\right)-\left(\sum \mathrm{x} 1 \mathrm{x} 2\right)\left(\sum \mathrm{x} 1 \mathrm{y}\right)}{\left(\sum \mathrm{x} 1^{2}\right)\left(\sum \mathrm{x} 2^{2}\right)-\left(\sum \mathrm{x}_{1} \mathrm{x}_{2}\right)\left(\sum \mathrm{x}_{1} \mathrm{x}_{2}\right)} \\
\mathrm{a}=\frac{\sum \mathrm{Y}-\mathrm{b}_{1} \sum \mathrm{x}_{1}-\mathrm{b}_{2} \sum \mathrm{x}_{2}-\mathrm{b}_{3} \sum \mathrm{x}_{3}-\mathrm{b}_{\mathrm{n}} \sum \mathrm{x}_{\mathrm{n}}}{\mathrm{n}}
\end{gathered}
$$

The test tool used to see the effect was multiple regression, while to see the pattern of the relationship, the partial correlation was used with a certain level of significance $(\alpha=5 \%)$. The criteria set are:

1) To determine all significant variables by looking at $t$ count and $t \alpha D F$, if $t$ arithmetic $>$ $\mathrm{t} \alpha$; DF then is meaningful

\begin{tabular}{|c|c|c|c|c|}
\hline $\begin{array}{l}\text { Statistik } \\
\text { Variable }\end{array}$ & $\mathrm{X} 1$ & $\mathrm{X} 2$ & $\mathrm{X} 3$ & $\mathrm{X} 1-\mathrm{X} 3$ \\
\hline $\begin{array}{ll}\text { 1. } & \text { Regression } \\
\text { Coefficient }\end{array}$ & 0,3101 & 1,8619 & 1,3665 & \\
\hline 2. $\begin{array}{l}\text { Correlation } \\
\text { Coefficient }\end{array}$ & 0,9024 & 0,9024 & 0,9024 & \\
\hline $\begin{array}{ll}\text { 3. } & \text { Determination } \\
\left(\mathrm{r}^{2}\right)\end{array}$ & 0,2671 & 0,1755 & 0,1995 & \\
\hline 4. Q. Count & 2,766 & 2,114 & 1,524 & \\
\hline 5. Q. Table & 1.721 & 1755 & 1,721 & \\
\hline $\begin{array}{ll}6 . & \text { Multiple } \\
\text { Coefficients } \\
(\mathrm{R})\end{array}$ & - & - & - & 0,9024 \\
\hline $\begin{array}{l}\text { 7. Multiple } \\
\text { Determination } \\
\text { (R2) }\end{array}$ & - & - & - & 0,8143 \\
\hline 8. F count & - & - & - & 30,699 \\
\hline 9. $\quad \mathrm{F}$ table & - & - & - & 2,84 \\
\hline Information & Significance & Significance & Significance & Significance \\
\hline
\end{tabular}

2) Receive $\mathrm{H} 0$ if $\beta \times 1 \geq \beta \times 23$

\section{Result}

Table 1. Data Analysis and Interpretation

Information:

The independent variable

$\mathrm{X} 1=$ responsibility

$\mathrm{X} 2=$ Loyalty

$\mathrm{X} 3$ = Obedience

Dependent variable

$\mathrm{Y}=$ Productivity

4.1 Hypothesis Testing

a. Hypothesis Testing 1

Based on the calculation table presented in the recapitulation of the results of multiple correlation testing of the relationship between the dependent variable and the independent variable, it turns out that F count (30.669)> F $\alpha$; DF (2.84), then $\mathrm{H} 0$ is accepted so that the first 
empirical hypothesis is proven or in other words that the factor -the factors of the responsibility variable (X1), the loyalty variable (X2), and the variable (X3) together affect Productivity (Y). Thus the hypothesis testing is proven.

b. Hypothesis testing 2

Based on the table above, it can be seen that all significant variables ( $t$ count $>t \alpha$; DF) and X1 are the most significant, so the second empirical hypothesis is proven that the responsibility variable (X1) has the most significant effect on Productivity (Y) among the loyalty variables (X2) and obedience. (X3) is thus testing

4.2 Interpretation of test results

From the calculation results in the table, it can be interpreted that the influence of the independent variables on the dependent variable is as follows:

a. From the test results, it can be explained that together the independent variables of responsibility (X1), loyalty (X2), obedience (X3) affect the dependent variable Productivity (Y).

An employee who has work loyalty is diligent and obedient; the employee's ability to comply with all applicable official regulations, has high dedication and responsibility, namely the ability to complete the assigned tasks so that productivity can increase. With the support of loyalty and obedience to work, it is hoped that it can improve employees' work efficiency, the responsibility given by the company with the hope that employees can complete their tasks [10]; [11]. Thus the existence of responsibility, loyalty, and obedience, employees will have high morale so that job satisfaction will be seen from the work results of each employee [12].

b. Based on the test results of the three independent variables, it is known that responsibility (X1) has the most significant effect on employee performance appraisal because this responsibility is always the hope of the appraiser to carry out company activities so that the production process runs smoothly and Work productivity increases so that that performance will be seen from the work results of each employee. Besides that, supported by loyalty and obedience to work are expected to increase employee work efficiency [13]. If the responsibilities given by the company are in accordance with what employees expect, then the employees will have high morale so that job satisfaction will be seen from the results of each employee's work [14].

\section{Conclusion}

Based on the results of research conducted on employees as respondents to the textile company "PT. Tootal Thread Indonesia "in Pasuruan, conclusions can be drawn according to the problem and research objectives.

1. The problem of this research is

- To what extent is the influence between the variables of responsibility (X1), loyalty (X2), and obedience (X3) on employee work productivity (Y)

- Among the responsibility factors (X1). Loyalty (X2) and Obedience (X3) what factors have the most meaningful effect on employee work productivity (Y).

2. Based on the above problems, the empirical hypothesis can be drawn as follows:

- It is assumed that the factors of responsibility (X1), loyalty (X2), and obedience (X3) have a significant effect on employee productivity (Y)

- It is assumed that responsibility (X1) is the most meaningful towards employee work productivity (Y)

3. A theoretical study exists in the face of several variables: responsibility, loyalty, obedience, and work productivity.

4. Based on testing and research results show that together with the influence of the variables of responsibility, loyalty, obedience because these factors are the driving force for employees to do a better job as well as driving the increase in employee productivity, 
5. The variable of responsibility (X1) has the most significant effect on work productivity (Y) because this responsibility is always hoped for the appraiser to carry out company activities so that the production process runs smoothly and work productivity increases.

6. After knowing the influence pattern equation between the independent variables and the dependent variable, it can be concluded that the responsibility variable has the most significant effect on work productivity, so it needs to be improved so that employee morale can also increase.

\section{Suggestions} made:

Based on the research results and analysis results obtained, the following suggestions can be

1. Considering that all independent variables influence the dependent variable and the responsibility factor, which significantly encourages work productivity with the most meaningful effect, a situation must be created to increase employees' responsibility. This can be achieved by paying attention to employees in terms of responsibility.

2. To increase employee work productivity, the company can impose sanctions or warnings for employees who are not responsible for carrying out their work so that a sense of belonging and responsibility will arise in the employees.

3. To further strengthen all the empirically proven hypotheses to be accepted, it is necessary to carry out repeated studies either using the same conception model or by adding several other variables that can describe the phenomena that arise in increasing employee productivity.

\section{References}

[1] A. Wæraas and D. Y. Dahle, "When reputation management is people management: Implications for employee voice," Eur. Manag. J., vol. 38, no. 2, pp. 277-287, 2020.

[2] D. Sirota and D. Klein, The enthusiastic employee: How companies profit by giving workers what they want. FT Press, 2013.

[3] B. Ozkeser, "Impact of training on employee motivation in human resources management," Procedia Comput. Sci., vol. 158, pp. 802-810, 2019.

[4] K. R. Murphy and J. N. Cleveland, Understanding performance appraisal: Social, organizational, and goal-based perspectives. Sage, 1995.

[5] N. Hadari, "Manajemen sumber daya manusia untuk bisnis yang kompetitif (Yogyakarta." Gadjah Mada University Press, 2003.

[6] A. Ahyari, "Manajemen Produksi Perencanaan Sistem Produksi, Edisi Empat," Yogyakarta BPFE, 2002.

[7] M. V. Rocco, Primary exergy cost of goods and services: an input-output approach. Springer, 2016.

[8] K. Barefoot, D. Curtis, W. Jolliff, J. R. Nicholson, and R. Omohundro, "Defining and measuring the digital economy," US Dep. Commer. Bur. Econ. Anal. Washington, DC, vol. 15, 2018.

[9] G. Sharma, "Pros and cons of different sampling techniques," Int. J. Appl. Res., vol. 3, no. 7, pp. 749-752, 2017.

[10] M. Noon, P. Blyton, and K. Morrell, The realities of work: Experiencing work and employment in contemporary society. Macmillan International Higher Education, 2013.

[11] A. Tannenbaum, Social psychology of the work organization (RLE: Organizations). Routledge, 2013.

[12] M. Asrar-ul-Haq, K. P. Kuchinke, and A. Iqbal, "The relationship between corporate social responsibility, job satisfaction, and organizational commitment: Case of Pakistani higher education," J. Clean. Prod., vol. 142, pp. 2352-2363, 2017. 
[13] E. D. Yanti and A. Sanny, "The Influence of Motivation, Organizational Commitment, and Organizational Culture to the Performance of Employee Universitas Pembangunan Panca Budi," Int. J. Res. Rev., vol. 6, no. 10, pp. 176-184, 2019.

[14] A. P. Mangkunegara and T. R. Octorend, "Effect of work discipline, work motivation and job satisfaction on employee organizational commitment in the company (Case study in PT. Dada Indonesia)," Marketing, vol. 293, pp. 31-36, 2015. 